\title{
Modern Greek Church Fairs and Pilgrimage Tourism
}

\author{
$\mathrm{PhD}$, Manolis Varvounis \\ $\mathrm{PhD}$, Nicos Rodosthenous
}

Democritus University of Thrace C. D. A. College of Cyprus

\begin{abstract}
The systematic study of church fairs, especially those of urban parishes in large urban centers, as carried out in recent years, has shown that there are many new customary and ritual forms that are created and adopted, often transformed to be enriched and made more attractive to the people. In this notice we will deal with certain interesting aspects of this contemporary customary reality. Through this adoption of customary forms, with their subsequent changes and amendments by the people on the basic characteristics of its live tradition, both the renewal of the tradition and the enrichment of the customary life of the people is achieved. This, in turn, is essential for the vitality and the continuation of the social impact and the acceptance of the tradition, which is an active procedure in progress, and not a set of fossilized situations, things, opinions, and actions. This is directly connected to the interior pilgrimage tourism since the organized visits of the believers to a place are frequent, specifically in order to take part in some great religious festival, which takes place there. In this process, the so critical from a cultural perspective since it's linked to the substance of our daily tradition itself, the novel elements of our contemporary religious fairs are critical points, as shown above in detail.
\end{abstract}

Keywords: pilgrimage tourism, urban parishes, church fairs, tradition.

\section{Introduction}

The systematic study of church fairs, especially those of urban parishes in the large and populous urban centers, as carried out in recent years, has shown that there are many new customary and ritual forms that are created and adopted, often transformed to be enriched and made more attractive to the people. With several of them, we have dealt systematically, under previous specific studies and publications. With some equally interesting aspects of this modernist customary reality, we will deal below.

At this point it should be noted that due to the known phenomenon of the export of cultural forms from the city to the provincial towns and villages, which is largely due to the television and the electronic media, or accelerated by them, these forms, that are normally created in large cities, today are spread and found all around the Greek cultural area. This is an important phenomenon that has been studied systematically by Edward Bailey ${ }^{1}$, that tends to homogenize the customary events, and which is responsible for the enrichment of the older customary and ritual tradition with novel data.

In this case, important and noteworthy is the role of the electronic agencies of ecclesiastical news, but also of the websites that are built and posted by Metropolises and also by most of the parishes of the Church of Greece. References, descriptions, and photos of the fairs of those parishes, enhanced occasionally by the relevant comments of these electronic pages users, always give information material and provide role models for reproduction to those who want to adopt new forms to the annually conducted festivals of their parishes ${ }^{2}$.

\footnotetext{
1 Edward Bailey, Implicit Religion: an introduction, Middlesex University Press, 1998, pp. 56-58. Idem, «The Folk Religion of the English People», in Religion, State and Society in Modern Britain, London 1989, pp. 145-158.

2 Justin L. Barrett, «Coding and quantifying counterintuitiveness in religious concepts: Theoretical and methodological reflections», Method \& Theory in the Study of Religion 20.4 (2008), pp. 308-338.
} 
On the other hand, it should be noted that what is described here is primarily related to parish fairs, since at the fairs of the chapels that are scattered in the Greek area, normally a different protocol is kept, more connected with the older ritualistic forms. Certainly, novel elements exist also in these "cottage" fairs ${ }^{1}$, but these have mainly to do with the action and the activity of associations in organizing the entertainment following the religious acts and sequences, not the main body of the fair itself.

As reported on another occasion, the effects in our contemporary church fairs by the public ritual and its various manifestations are many and important. The presence of philharmonics, usually municipal, of military units or formations of the area or even associations operating there, and the fireworks, especially during the festive procession of the image of the celebrated saint, are typical cases of such relations and effects².

\section{Some cases}

Specifically, the following phenomenon is noticed, whereas previously philharmonics accompanied church processions and events generally held in capitals of prefectures, today, philharmonics are invited by celebrating parishes of villages, precisely because it is believed that their presence adds a festive, symbolic and ritual status in the process. And so, whereas previously the presence of the philharmonic in religious and church services was linked inextricably with the chorostasia of the Metropolitan concerned and the attendance of civil and military authorities at the temple, so it clearly derived from the public of rituals of the relevant national and local holidays, which secondarily combined with the church life and practice, today the philharmonic is often a key element of the fair, even if the other components of the public ritual are absent ${ }^{3}$.

The same thing can be noticed with the fireworks too, which in the 70s, for example, just accompanied public festivals and fairs. Nowadays, since they became more economically accessible, and also the administrative and police procedures for obtaining and using them are changed and simplified, they appear more and more. Not only in official parish fairs, especially at the end of the procession of the holy image 4 or after the dismissal of the celebratory eve's vesper, but also in important traditional moments in the life cycle fireworks are used. Thus, we now see them in baptisms and weddings, in the courtyard of the temple after the end of the mystery or at the venue where the reception or party is conducted.

In any case, the use of fireworks is defined by the notion that they give to the festival ritual prestige and glory, that in a symbolic way they establish and formalize, in the realm of public ritual, a more or less private ritual. It is also standard practice of the Church in Greece to try to emphasize in every possible symbolic and non-symbolic way its close relation to the state, its structures and its manifestations, with the belief that it acquires thus prestige and authority in the eyes of its flock ${ }^{5}$. This is also the ocassion in the life cycle sacraments (baptism - marriage), where the private is symbolically displayed to the public sphere, in order to obtain symbolic social status (prestige).

In the same category of modernist ritual acts the tactic to invite many priests and prelates to the festival may be added, a practice which will be particularly studied, and also the authorities of the place or the municipality where the temple is celebrated. And as for the notification of the festival to the urban area the practice of issuing and suspending specific posters 6 is used now, respectively the invitation of the "officials" is made with special written invitation, which is sent to them signed by the Ecclesiastical Council and the head priest of the festive and celebrating parish.

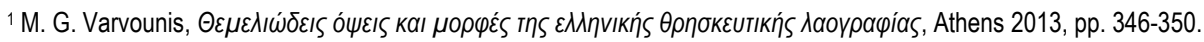

2 Cf. Ol. Bockhorn - H.P. Flelhauer, «Kulturelles Erbe und Aneignung», Festschrift für Richard Wolfram zum 80. Geburtstag, Wien 1982, pp. 207-232.

${ }^{3} \mathrm{Ph}$. Boutry, «Les mutations du payage paroissial. Reconstructions d' eglises et translations de cimetieres dans les campagnes del' Ain au XIXe siècle», Ethnologie Française 15 (1980), pp. 7-32.

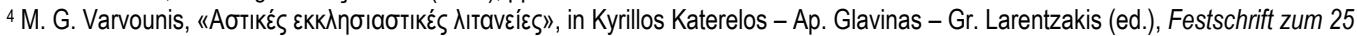
jährigen Jubiläum der Bischofsweihe und 20 jährigen Jubiläum Metropolit von Austria und Exarch von Ungarn und Mitteleuropa Dr. Michael Staikos, Athens 2011, pp. 67-75.

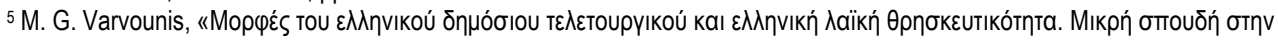

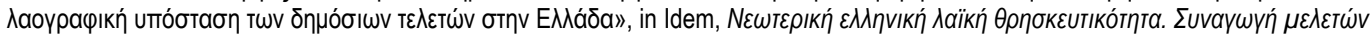

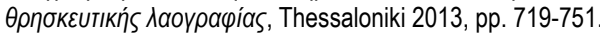

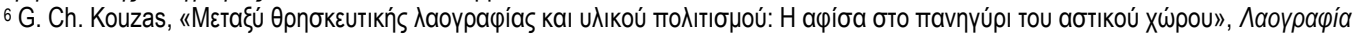

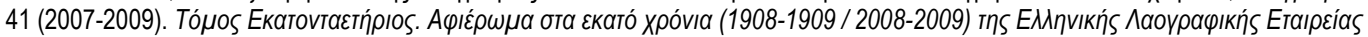

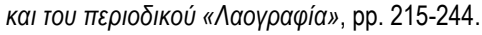


Such invitations are typically sent to MPs, mayors, deputy mayors and municipal councilors, to the regional governor, the deputy regional governors and the regional consultants of the region, but also to judicial, military and police authorities of each municipality or the specific region, as well as to association and union presidents. Characteristic of the convergence of the public and ecclesiastical ritual is the use of the known invitation protocol, which the Metropolises usually take by the Municipalities, the Prefectures, and the regional districts, and then the churches receive it by the Metropolises and use it. It should be noted here that normally the protocol is in a shortened ("short protocol") and extensive ("long protocol") form, depending on the occasion and the purposes of the inviter. In this way, the body of the "officials" will always have a similar composition, so that at the church act all the local rulers will also distinguish from the people who attend and participate in the festival ${ }^{1}$ too.

This diversity in addressing the celebrants, the distinction between "officials" and others, is clearly a modernist practice that does not essentially agree with the equality of believers in the Church, substantiated by the evangelical speech and the patristic theology. But it is common practice, normally due to the attachment of the Church in the state structure and operation system, which is thus expressed in absolutely symbolic level, and which has been mentioned elsewhere too?

An equally interesting modernist addition to the fairs' protocol is the transformation "to the more modernist" of old and established customary practices and religious rituals. A typical example is the outdoor Artoklasia. The solemn procession of Artoklasia, normally celebrated inside the temple or its courtyard, if the celebrating temple is small or the weather conditions are such that they do not favor the crowding of the believers, is sometimes transferred to the settlement or municipality Square but also on the beach of the seaside city, during the principal stop of the solemn procession of the image of the saint, usually the night before, after the solemn vesper.

This practice, combined with other modernist practices such as the use of fireworks and the related celebratory speeches, which will be discussed below, is in proportion to the practice of the establishment of new fairs by the local Metropolitans, normally dedicated to the "congregation" of local saints in a region or a Metropolis. Because these newly listed celebrations are usually held during summer, the respective religious events are organized in a way that they offer spectacle to the site visitors and also a rallying point for the emigrants of the region, who are in their homelands during summer. It is characteristic that similar trends are observed in other Christian peoples of Europe, as it has been ascertained by Ellen Ettlinger ${ }^{3}$, on the basis of relevant English examples.

So the artoklasia is conducted during the litany, on a stand, and the bread is shared after the return to the celebrating temple and the end of the procession, usually by the head priest of the religious congregation. In fact the practice of bread cut and placed in bags individually, distributed by the high priest along with paper benediction images ${ }^{4}$, that serve as mementos of participation in the festival, is followed. For the "officials" mentioned above, but also for the invited priests of other parishes, specially formulated buns are prepared, usually sweet, sometimes with the offering stamp imprinted on their surfaces, which are usually given in special cartons ${ }^{5}$. The same happens with the eminent persons in the region, parishioners with a significant contribution in the parish, donors and benefactors, etc.

It should also be noted here that a similar way of offering and flowers by the flower decorations of images, the epitaph and the cross of Holy Thursday, as well as cottons with Extreme unction, when carried out in the church, or even small bottles with oil from the lamp of the saint or sanctification, can be found in many cases. They are usually organized parishes, populous in general, who resort to similar solutions for utilitarian purposes, but also in their efforts to ensure the jeopardized

\footnotetext{
1 José Casanova, «Religion, the new millennium, and globalization», Sociology of Religion 62.4 (2001), pp. 415-441. Cf. Donald E. Byrne Jr, «Folklore and the Study of American Religion», in Charles H. Lippy - Peter W. Williams (ed.), Encyclopedia of the American Religious Experience 1, London 1988, pp. 85-100.

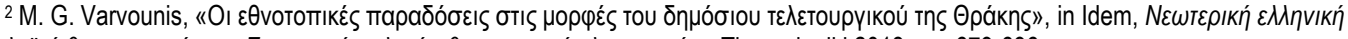

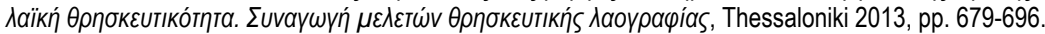

${ }^{3}$ Ellen Ettlinger, «Folklore in Oxfordshire Churches», Folklore 73.3 (1962), pp. 160-177.

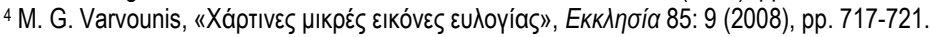

5 Claudia Fonseca, «La religion dans la vie quotidienne d'un groupe populaire brésilien», Archives de Sciences Sociales des Religions 112 (1991), pp. 125-139. Wilhelmus Th. M. Frijhoff, Problèmes spécifiques d'une approche de la religion populaire'dans un pays de confession mixte: le cas des Provinces-Unies, CNRS, 1979, p. 47 к.ع..
} 
order and decorum of the church when the customary occasion and the liturgical circumstance require similar "sacred distributions"1.

\section{Local and cultural identity}

These modernist additions often extend to the case of preaching, which is theologically established and an essential element of the service, always within the framework of divine worship. Already since the time of St. Cosmas of Aetolia but also later with the preachers of the 19th and the $20^{\text {th }}$ century, some of whom were laymen, and with the work of religious brotherhoods in Greece, the tradition of preaching also outside the context of divine worship, for the purpose of spiritual training and mental construction, has established in the minds of our people. In the cases we examine, an interim modernist form has formed, that clearly interests the context of religious folklore, as we define it and examine it here.

These are speeches normally performed by priests or head priests who chair the related processions, and which essentially replace the sermons, as their content is not exclusively beneficial to the soul, like them. Often, of course, they start with the example of the celebrated saint to make admonitions and exhortations to the believers, but the ending of speech is different, since it acquires social and "political" content, with thanks to the local officials who honoured the festival with their presence.

The main point of the festive oratory of these speeches ${ }^{2}$, refers to the Orthodox Church as guarantor of traditions and the preservation of the cultural, ethnic and religious identity of the Nation. This oratory projects similar church actions, and gives the church life also extensions beyond the purely spiritual and salvific effort of the Church, with the development of a characteristic for the Greek reality close connection of the Church with the Nation, the ethnicity and their identity. It is a peculiarity of the Greek ecclesiastical reality, which of course is due to historical circumstances, as indeed for centuries the Greek orthodox identity was simultaneously a national and cultural declaration.

Depending on the personality and the ideological origins of the talking, these newly listed religious fairs have national and cultural extensions, and are projected as coherent links of those originating from the same place, the "countrymen" and "compatriots" in the broadest sense. And the basic ideological line of these speeches fits with the usual events of the local associations, or local branches of the Lyceum of Greek Women, who after the artoklasia and the completion of the litany, normally in the same room, they dance traditional dances of the region or nationwide known ${ }^{3}$.

Inherent in these events is the ideologically charged connection of folk culture with certain "traditional" celebrational moments, which requires, for example, on Easter Sunday television stations to show broadcasts that fall within the limits of 'staged authenticity't with bands who dressed in "traditional dresses" dance relevant dances, representing generally in a folklore way, older forms of Easter customs in their area. Here it is absolutely typical that the worship and church life falls in the folklore self-determination of the "local identity"s, and that through the support of such actions, the Church strongly asserts the role of the protector but also of the eminently genuine exponent of this tradition.

Of course, to a certain extent, this is absolutely justified, as in modern Greek society, the Church is one of the few living institutions in which the people has complete trust since they see the ways it operates today. This assumption is what

\footnotetext{
1 Joseph Klapper, Religiöse Volkskunde im gesamtschlesischen Raum: Grundlagen und Aufgaben, P. Pattloch, 1953, б. 35 seq. 2 Jeanne Kormina, «Pilgrims, priest, and local religion in contemporary Russia: Contested religious discourses», Folklore 28 (2004), pp. 25-40. Karl Sigismund Kramer, Grundriß einer rechtlichen Volkskunde, Schwartz, 1974, p. 68 seq. Josef Kreiner, «Some Problems of Folk-Religion in the Southwest Islands (Ryukyu)», in Folk Religion and the Worldview in the Southwestern Pacific, New York 1968, pp. 101-118. Mark Kriger - Yvonne Seng, «Leadership with inner meaning: A contingency theory of leadership based on the worldviews of five religions», The Leadership Quarterly 16.5 (2005), pp. 771-806.

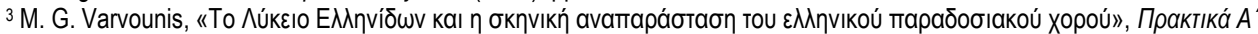

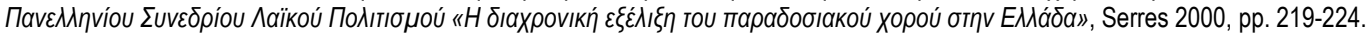

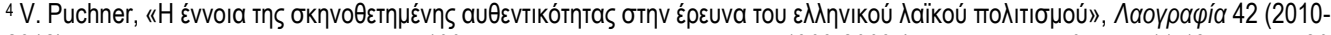

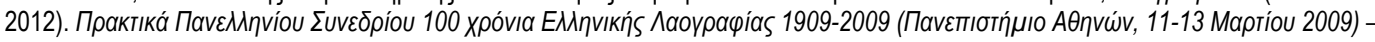

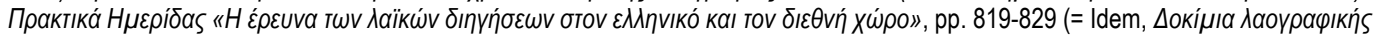
$\theta \varepsilon \omega p i a s$, Athens 2011, pp. 69-81).

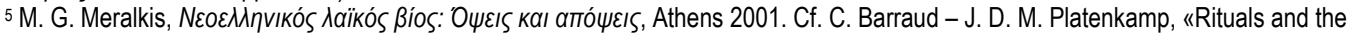
comparison of societies», in C. Barraud - J. D. M. Platenkamp (ed.), Rituals and Socio-cosmic Order in Eastern Indonesian Societies 2, Bijdragen 1990, pp. 23-24.
} 
explains both the ecclesiastical oratory in the celebrational circumstances that are examined here, and the great popular participation in them, considering also the love factor of the people for public ceremonial forms and actions.

A modernist phenomenon is also the connection of the fair, long-established or newly listed, with the organisation of a series of events, which usually take their name from the celebrated saint (eg "Taxiarcheia", "Nikodimeia ", "Theotokia", "Theomitorica ", "Evangelistria"etc. ) and are contacted in temporal relevance to the fair, starting before it and ending after its end.

These events have a triple nature, worship, spiritual and artistic, and usually their contents, sometimes spread in duration up to a month, are imprinted in special posters, programs, and invitations, sent or posted, in order to make them public and attract people. In fact in the recent years electronic posting and notification has started, as the use of Internet and new technologies is increasingly spreading in the church.

The worshiping part of these events includes the conduction of various sequences, beyond the established festive ones, always coherent with the well-known and miraculous images or any holy relics transferred to the celebrating church for the holiday, according to a major modernist religious practice, which is discussed in detail on another occasion. These are liturgies, pre-sanctified if it is Lent, vespers, vigils, and prayers, always combined with preaching and relevant treats by the church.

The spiritual part is covered with the organization of meetings, small conferences or lectures, which generally have a religious and theological content, but are often spread on related sciences too, such as history, literature and folklore ${ }^{1}$. The topics of these events are generally varied and conducted in cultural centers and parishes' halls, or in halls and conference centers of the Metropolises where they belong. The participants are intellectuals and scientists of the parish, and also widely known authors and researchers in the spiritual and ideological field, which generally major audiences follow ${ }^{2}$. In fact in some cases, these spiritual and scientific events are held inside the temples.

\section{Artistic aspects}

The artistic aspect of these events has also various themes. It includes from paintings, crafts mainly from workshops and schools organized and operated in the area of the parish and photography, to music and dance events. In fact the latter, in the frame of the above mentioned, are mainly located in the area of church and folk music, but without excluding classical music concerts, church music of other Orthodox peoples (eg Russian) and choral presentations. Often these events include items for sale, which will strengthen the parish fund, or are part of Charity actions, that exist in almost all parishes, and to which the maintenance and support of the charitable activities of the different parishes ${ }^{3}$ are often owed.

In some cases, when the festival coincides with a national or other commonly known holiday, and when the time of year favors it, these events include also theatrical performances, presentation of the work of amateur artistic groups, even large music concerts, whose revenue will strengthen again the parish fund. Sometimes school and student competitions are included again in the same context, with the goal to write a text or the production of a work of art, the theme of which revolves around the celebrated saint, or around values, ideals, and messages that the Church has chosen to project.

Basically, these events have as a common axis the projection of the honored saint, his life, and his life model, and also the parish work and the parish as a whole. Nowadays, with these events, a new parish perspective is essentially constructed, expressed primarily through the novel phenomena replicated here ${ }^{4}$. This modernistic parish spiritual and ideological identity is also documented by the keepsakes given in these celebrations to all participants, diplomas, plaques and medals, where

\footnotetext{
1 Benoît Lacroix - Jean Simard, Religion populaire, religion de clercs? 2, Quebec, 1984, p. 123 к.દ६. Benoît Lacroix, «L'Oratoire SaintJoseph (1904-1979), fait religieux populaire», Cahiers de Joséphologie Montréal 27.2 (1979), pp. 255-265. Roger Lapointe, Socioanthropologie du religieux: la religion populaire au péril de la modernité 1, Librairie Droz, 1988.

2 Jacques Maître, «Religion populaire et populations religieuses», Cahiers Internationaux de Sociologie 27 (1959), pp. 95-120.

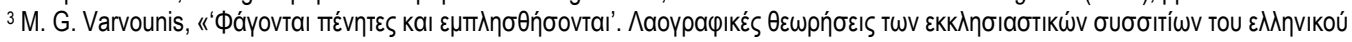

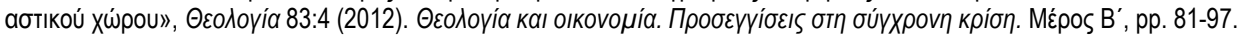

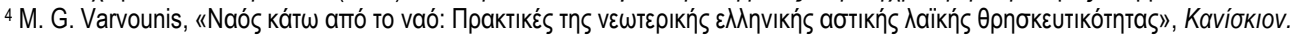

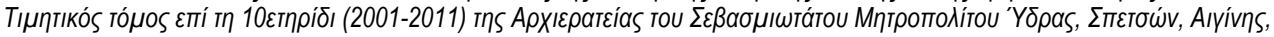

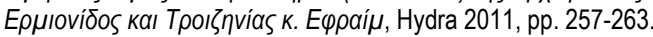


the emblems of the parish, as well as representations and signals of emblematic content are clearly reflected, in trying to perpetuate the fair beyond the specific timing.

In this direction also leads the yearly repetition of these events, with greater or more limited scope, depending on the circumstances and the specific situation data, but with the clear statement that it is a continuation of the preceding. The continuity in time proves the establishment, and this factor is a condition of self-righteousness for the contributors of such parish events ${ }^{1}$, which should be highlighted that are purely voluntary, with minimized expenses, propped on volunteers and partners, generally folksy, active in every parish.

Besides, we should not forget that in the category of modernist parish events are also included all kinds of educational activities, which the parishes organize and carry out, with the aim of gathering and bringing together people, especially young people, around the parishes. After 2009, the economic crisis of Greek society, which becomes more and torturously felt in large urban centers, led to a concentration of various social functions around the parishes, to the level of free offer to people who cannot pay for them: food, schools for students, purchase of medicines, clothing and even medical care often covered at parish level, by church resources².

Already before the outbreak of the crisis, the parishes offered for free knowledge and skills, within their social work: painting lessons, music and dance, cookery and craft courses (woodwork, copper art, jewellery making, etc. ), and even foreign languages lessons and providing basic medical and legal knowledge are some of the areas in which the parish work spread. The students of those, basically afternoon, classes, often exhibit their works - with any revenue from the sales to primarily strengthen the parish fund - and actively participate in the events referred to here.

Basically is another aspect of the contributing to society of the parishes of the cities, in the sense that the joint participation in such actions under the auspices of the Church, most often creates or rebuilds and transforms social relations, becoming an essential social unity factor and enhancing the local community ties in the wider operating area of these parishes ${ }^{3}$. And it is this social role, which in final analysis places particular emphasis to these actions, making them the most beloved collective events among people, beyond their obvious religious, intellectual and functional significance for the believers of our times 4 .

\section{Conclusion}

The novel elements of our above mentioned contemporary church fairs, are typical aspects of the contemporary also Greek popular religiosity, which the religious folklore studies. Aspects important for the study of the forms our modern sense of tradition takes, and the transformations the older forms undergo, while the tradition process traverses human societies over time.

In these forms coexist both developments and older data transformations, as much as new forms, adopted either from abroad or from other sectors and divisions of the organized social life. In fact, it should be noted that in the religious folklore we cannot refer to "our own" and "foreign" elements, since from the moment an element of the traditional religious behaviour is adopted by the people, it becomes a fact of the folklore of the given place and time ${ }^{5}$. So the adoption of forms from the

\footnotetext{
${ }^{1}$ Cf. Elaine J. Lawless, «Brothers and sisters: Pentecostals as a religious folk group», Western Folklore 42.2 (1983), pp. 85-104.

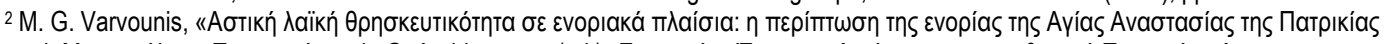

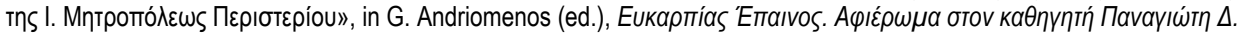

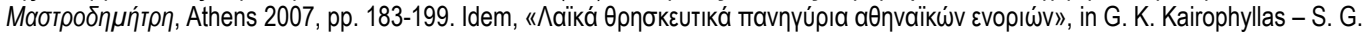

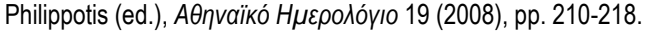

3 Hitoshi Miyake, «Folk religion», in Religion in Japanese culture: where living traditions meet a changing world, New York 1996, pp. 7996. Idem, Shugendō: essays on the structure of Japanese folk religion, Center for Japanese Studies, the University of Michigan, 2001. Cf. P. A. Morris, «The effect of pilgrimage on anxiety, depression and religious attitude», Psychological Medicine 12.2 (1982), pp. 291294.

${ }^{4}$ Roberto Motta, «Ethnicité, nationalité et syncrétisme dans les religions populaires brésiliennes», Social Compass 41.1 (1994), pp. 6778. George MacDonald Mulrain, Theology in Folk Culture: The Theological Significance of Haitian Folk Religion, P. Lang, 1984. Arnaldo Nesti - F. Dassetto - A. Bastenier, «Gramsci et la religion populaire», Social Compass 22.3-4 (1975), pp. 343-354.

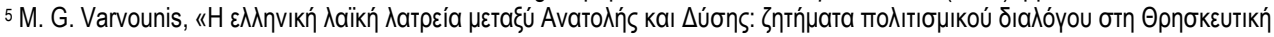

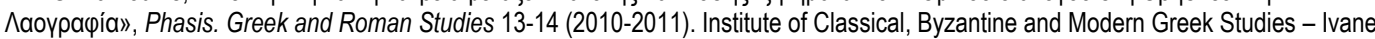
Javakhishvili Tibilisi State University, pp. 416-434.
} 
people, which inevitably means the beginning of a series of changes and transformations, is the critical point after which we cannot talk about outlandish customs, but for manifestations of the single folklore.

Through this adoption of forms, with their subsequent changes and amendments, or rather the "stochastic adjustments" of the basic characteristics of the live tradition by the people, the renewal of the tradition is achieved, as much as the enrichment of the customary life of the people ${ }^{1}$. This, in turn, is essential for the vitality and the continuation of the social impact and the acceptance of the tradition, which is an active procedure in progress, and not a set of fossilized situations, things, opinions, and actions ${ }^{2}$. And this happens even in the case of popular religious tradition, no matter how cumbersome and slow in development these by definition conservative and typically almost repeated religious and liturgical traditions of a people are ${ }^{3}$.

In this process, the so critical from a cultural perspective since it's linked to the substance of our daily tradition itself, the novel elements of our contemporary religious fairs are critical points, as shown above in detail.

Bibliography

[1] Ambrosio, V. (2007), «Sacred pilgrimage and tourism as secular pilgrimage», in the volume Religious tourism and pilgrimage festivals management, New York, pp. 78-88.

[2] Belisle, F. J. -Hoy, D. R., (1980), «The perceived impact of tourism by residents a case study in Santa Marta, Colombia», Annals of Tourism Research 7: 1, pp. 83-101.

[3] Brice, J. - Busby, G. - Brunt, P. (2003), «English rural church tourism: a visitor typology», Acta Turistica 15: 2, pp. 144162.

[4] Busby, G. (2002), «The Cornish church heritage as destination component», Tourism (Zagreb) 50: 4, pp. 371-381.

[5] Church A. - Coles T. (2007) (eds. ), Tourism, power and space, Psychology Press.

[6] Coles T. -Church A. (2007), «Tourism, politics and the forgotten entanglements of power», in the volumeTourism, power and space, London, $\sigma .1-42$.

[7] Collins-Kreiner N. (2006), Christian tourism to the Holy Land: Pilgrimage during security crisis, Ashgate Publishing, p. 156.

[8] Collins-Kreiner, N. -Kliot, N. (2000), «Pilgrimage tourism in the Holy Land: the behavioural characteristics of Christian pilgrims», GeoJournal, 50: 1, pp. 55-67.

[9] Dallen, T. J. (2007), «Empowerment and stakeholder participation in tourism destination communities», in the volume Tourism, power and space, London, pp. 199-216.

[10] Fabre-Vassa, C. (1995), «Paraschiva-Vendredi. La sainte des femmes, des travaux, des jours», Terrain 24, pp. 6264.

[11] Fähnrich, H. (1996), «Alter Herrgott. Zur Geschichte einer Waldkapelle», Die Oderpfalz 84:3, pp. 161-164.

[12] Haller, R. (1995), Einmal im Leben auf den Heiligen Berg. Grafenau, pp. 160-161.

[13] Hudman, L. E. -Jackson, R. H. (1992), «Mormon pilgrimage and tourism», Annals of Tourism Research 19: 1, pp. $107-$ 121.

[14] Kamil, J. (2000), «Religious tourism as big business», Al Ahram Weekly 469, pp. 12-14.

[15] Keeling, A. (2002), «Church Tourism-providing a ministry of welcome to visitors», English Tourism Council. Insights, London, pp. $12 \mathrm{ff}$.

\footnotetext{
${ }_{1}^{1}$ Sidbe Sempore, «Religion populaire en Afrique. Le Bénin, un cas typique in Religion populaire», Concilium 206 (1986), pp. 63-70.

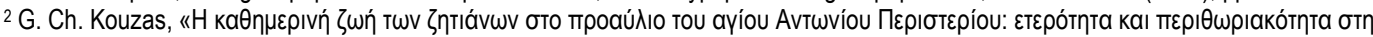

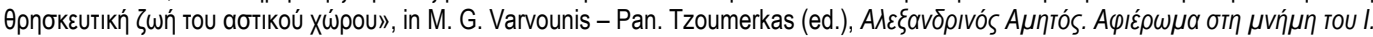

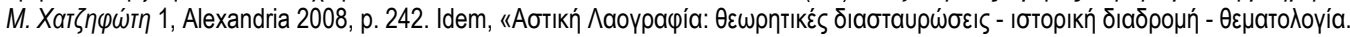

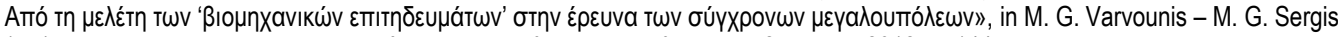

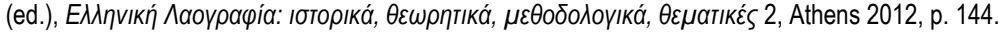

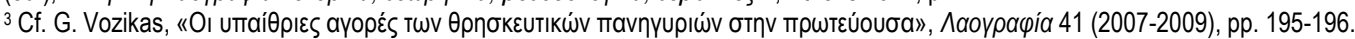


[16] McKelvie, J. (2005), «Religious tourism», Travel and Tourism Analyst 4, pp. 1-47.

[17] Milman, A. -Pizam, A. (1988), «Social impacts of tourism on central Florida», Annals of Tourism Research 15: 2, pp. 191-204.

[18] Morpeth, N. D. (2011), «Church tourism and faith tourism initiatives in Northern England: implications for the management of religious tourism sites», International Journal of Business and Globalisation 7: 1, pp. 93-101.

[19] Nolan M. L. -Nolan, S. (1992), «Religious sites as tourism attractions in Europe», Annals of Tourism Research 19: 1, pp. 68-78.

[20] Rinschede, G. (1992), «Forms of religious tourism», Annals of Tourism Research 19: 1, pp. 51-67.

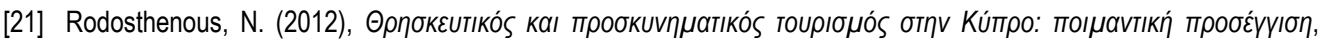
Thessaloniki (Unpublished PhD Dissertation, Aristoteleion University Thessaloniki - School of Theology/Department of Theology).

[22] Rotherham, I. D. (2007), «Sustaining tourism infrastructures for religious tourists and pilgrims within the UK», in the volume Religious tourism and pilgrimage festivals management, New York, pp. 64-77.

[23] Santos, X. M. (2002), «Pilgrimage and tourism at Santiago de Compostela», Tourism Recreation Research 27: 2, pp. 41-50.

[24] Schweigert, H. (1996), «Die Gnadenstatue und das "Schatzkammerbild" von Mariazell», in the volumeSchatz und Schicksal 1. Graz, pp. 89-100.

[25] Sharpley, R. (2009), «Tourism, religion and spirituality», The Sage pp. 23-46.

[26] Smith, M. K. -Robinson, M. (2006), Cultural tourism in a changing world: Politics, participation and (re) presentation, Channel View Publications, pp. $123 \mathrm{ff}$.

[27] Swatos, W. H. 2002, From medieval pilgrimage to religious tourism: The social and cultural economics of piety, Praeger Publishers, pp. 134-136.

[28] Theilmann, J. M. (1987), «Medieval pilgrims and the origins of tourism», The Journal of Popular Culture 20: 4, pp. 93102

[29] Tilson, D. J. (2005), «Religious-spiritual tourism and promotional campaigning: a church-state partnership for St. James and Spain», Journal of Hospitality \& Leisure Marketing 12: 1-2, pp. 9-40.

[30] Timothy, D. J. (1997), «Tourism and the personal heritage experience», Annals of Tourism Research 24: 3 pp. 751754.

[31] Tomasi, L. (2002), «Homo Viator: from pilgrimage to religious tourism via the journey», in the volume William H. Swatos (ed. ), From medieval pilgrimage to religious tourism: The social and cultural economics of piety, Praeger Publishers, pp. 1-24.

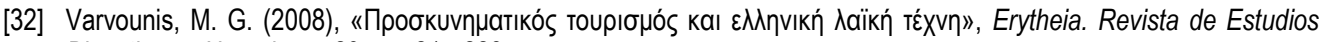
Bizantinos y Neogriegos 29, pp. 217-228.

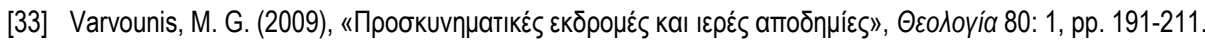

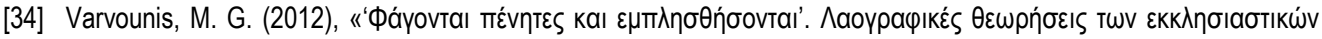

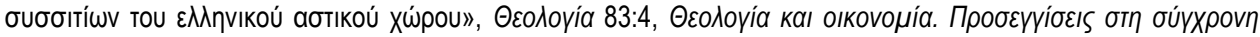

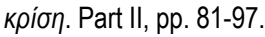

[35] Vukonic, B. (1996), Tourism and religion, Oxford: Pergamon.

[36] Watson, S. (2007), Church Tourism: Representation and Cultural Practice, Diss. University of York.

[37] Wilkinson, P. F. (1989), «Strategies for tourism in island microstates», Annals of Tourism Research 16: 2, pp. 153177.

[38] Woodward, S. C. (2004), «Faith and tourism: planning tourism in relation to places of worship», Tourism and Hospitality Planning \& Development 1: 2, pp. 173-186. 